IZA DP No. 4788

Does Immigration Induce 'Native Flight' from Public Schools?

Evidence from a Large Scale Voucher Program

Christer Gerdes

February 2010 


\title{
Does Immigration Induce 'Native Flight' from Public Schools? Evidence from a Large Scale Voucher Program
}

\author{
Christer Gerdes \\ SOFI, Stockholm University, SULCIS \\ and IZA
}

Discussion Paper No. 4788

February 2010

\author{
IZA \\ P.O. Box 7240 \\ 53072 Bonn \\ Germany \\ Phone: +49-228-3894-0 \\ Fax: +49-228-3894-180 \\ E-mail: iza@iza.org
}

Any opinions expressed here are those of the author(s) and not those of IZA. Research published in this series may include views on policy, but the institute itself takes no institutional policy positions.

The Institute for the Study of Labor (IZA) in Bonn is a local and virtual international research center and a place of communication between science, politics and business. IZA is an independent nonprofit organization supported by Deutsche Post Foundation. The center is associated with the University of Bonn and offers a stimulating research environment through its international network, workshops and conferences, data service, project support, research visits and doctoral program. IZA engages in (i) original and internationally competitive research in all fields of labor economics, (ii) development of policy concepts, and (iii) dissemination of research results and concepts to the interested public.

IZA Discussion Papers often represent preliminary work and are circulated to encourage discussion. Citation of such a paper should account for its provisional character. A revised version may be available directly from the author. 
IZA Discussion Paper No. 4788

February 2010

\section{ABSTRACT \\ Does Immigration Induce 'Native Flight' from Public Schools? Evidence from a Large Scale Voucher Program}

Recent studies point to a positive correlation between ethnic heterogeneity due to immigration and the propensity of opting out from public schools for private alternatives. However, immigration across regions is hardly exogenous, which obstructs attempts to reveal causal mechanisms. This paper explores changes in the immigrant population in Danish municipalities 1992-2004, a period marked by a substantial influx of refugees, where a statesponsored placement policy restricted their initial choice of residence. Besides such demographic changes, for more than hundred years Denmark has allowed parents to enroll their children into so called 'free schools', i.e. schools that are privately operated. Taken together, this provides a unique opportunity to determine if there has been 'native flight' from public schools to free schools. Results from this study indicate an increase in native Danes propensity to enroll their children in free schools as the share of children with immigrant background becomes larger in their municipality of residence. The effect is most pronounced in small and medium sized municipalities, while it seems absent in larger municipalities. One explanation for the latter holds that residential segregation within larger municipalities makes a choice of private alternatives less attractive.

JEL Classification: $\quad H 7$, I28, J15, J78, R5

Keywords: $\quad$ school choice, immigration, private schools

Corresponding author:

Christer Gerdes

Swedish Institute for Social Research

Stockholm University

SE 10691 Stockholm

Sweden

E-mail: Christer.Gerdes@sofi.su.se 


\section{Introduction}

In an influential study Betts and Fairlie (2003) coined the expression 'native flight', thereby denoting the tendency of native born Americans to abandon public schools for private alternatives following an increase in immigration shares in their home communities. That study was the first to focus on the impact of immigration on school choice, thereby extending the literature that so far mainly had focused on the interplay of minority groups and school choice, such as the share of Afro-Americans or Hispanics, see for example Fairlie and Resch (2001). The present study aims to study if there is evidence of 'native flight' in a somewhat different setting due to its focus on Danish municipalities. For more than a century, in Denmark privately operated schools have been an alternative to regular public schools. According to recent figures from the Ministry of Education, about $13 \%$ of children in the age group 5-16 attended privately operated schools in Denmark. Noteworthy is that these so called 'free schools' are recognized and entitled to "government financing regardless of the ideological, religious, political or ethnic motivation behind their establishment," see Danish Ministry of Education (2008). In practice this means that free schools receive predetermined amounts of tax-money for every pupil they enroll. Stated differently, while in most Western countries access to other educational forms than regular public schools has been restricted to certain groups, in Denmark the option of choosing among different educational tracks has been accessible for larger parts of its population for a long period of time. Such coexistence of public and privately operated school alternatives under the roof of a tax funded educational system provides a solid base for a study on 'native flight'. In particular, this follows from that large scale immigration has been a rather new incident in Denmark, meaning that access to privately operated schools were an option long before migration became an issue in Denmark. This facilitates to determine causal impacts of processes than what would be possible if school choice and large scale immigration would have emerged simultaneously. 
There are several reasons motivating a study looking at evidence for 'native flight'. First, as Betts and Fairlie (2003) point out, a negative effect of immigration on school attendance rates could weaken the support for tax financed education as parents might be unwilling to contribute to public schools by means of taxes at the same time as they pay fees for alternative ways of education (p. 989): "If parents with relatively high socioeconomic status decide to enroll their children in private schools as a result of immigration voter support for public schools may erode." Second, the issue of 'native flight' also relates to studies that aim to evaluate the impact of free choice on educational outcomes. ${ }^{2}$ Most studies concerned with the consequences of school choice are addressing educational outcomes, not least to examine the scope for efficiency gains arising from competition between schools. However, when looking at educational achievements of pupils in different schools it is important to resolve the mechanisms that underlie decisions on school choice per se. In particular, if there would be an increased tendency of abandoning public schools following an influx of pupils with a different ethnic background, this would question one underlying assumption made by advocates of free school choice, namely that parents are primarily concerned with educational standards. ${ }^{3}$ By addressing the native flight issue within a voucher based educational system (explained more in detail in the next section), this study relates to a large literature on the effectiveness of

\footnotetext{
${ }^{1}$ Dottori and Shen (2009) provide a political-economic model as to the way low-skilled immigration could affect school choices and a weakening support for public education.

${ }^{2}$ Most studies available draw attention to the US, where some have looked at private schools, while others have studied so called charter schools. The latter emerged in the beginning of the 1990s in some US states as an alternative to public schools. Charter schools are often started for the purpose of attracting certain minority groups “to keep students in school” (Tedin and Weiher, 2004, p. 1112).

${ }^{3}$ See Rothstein (2006) and Urquiola (2005), raising the issue of children sorting into different schools on grounds other than school efficiency, which blunt the impact of school choice on educational outcomes. One motive in school choice could be to ensure one's offspring to attend schools that are in line with the parents' religious identity. See Cohen-Zada (2006) for a theoretical model and empirical work on such mechanism.
} 
school vouchers for educational outcomes; see e.g. Ladd (2002) and references given there. ${ }^{4}$ A third factor to motivate this study regards the aspect of integration of immigrant groups into the host country by means of its educational system. Not the least, education will precondition their propensity to assimilate and integrate into the labor market. See e.g. Clark and Lindley (2009) for a recent study on the impact of pre-labor market assimilation in the UK.

In their study, Betts and Fairlie look at the changes in private school attendance rates within 132 metropolitan areas using US Census data for the years 1980 and $1990 .^{5}$ The present study has a similar approach in the way it looks at changes occurring over time across regions. One advantage here is that all years in 1992 to 2004 are included, rather than only two years of observation. In addition, the influx of pupils with immigrant background to different areas has to some extent been determined by exogenous events, as will be shown in subsequent sections. This allows for an analysis well suited for examining the interplay of school choice and immigration. ${ }^{6}$ One drawback of this study in comparison with the one by Betts and Fairlie (2003) is that the aggregated data used here does not allow for the control of individual-level characteristics, such as parents' education and household income. As to its empirical approach, this study is comparable to Hsieh and Urquiola (2006) in the way it

\footnotetext{
${ }^{4}$ See also Gibbons et al. (2008) for a discussion and references on theoretical explanations on possible mechanisms involved. As they point out, there are two main arguments for efficiency gains due to school choice. The first holds that more competition will enforce schools to adopt/improve 'teaching technologies'. The other argument holds that free choice will lead to better matches as pupils will sort into schools based on educational preferences and needs.

${ }^{5}$ About $85 \%$ of those enrolled in private schools in their sample attend religious (i.e. catholic) schools.

${ }^{6}$ Betts and Fairlie address endogeneity issues by using IV-estimations, where their instrument for demographic changes in 1980 to 1990 is the share of immigrants in the year 1980. Due to the rather small sample size of 132 metropolitan areas, these IV-estimates are not very precise and therefore rather unreliable.
} 
focuses on municipalities as "proxies for educational markets" (p.1486). They address both educational achievements as well as sorting as the consequences of the introduction of school vouchers in Chile. ${ }^{7}$

The main result from the present study point in the same direction as the Betts and Fairlie (2003) study, revealing an increase in the number of native pupils enrolled in non-public schools following an influx of immigrants. What can explain the positive elasticities in immigration shares and private school attendance rates in Denmark? Betts and Fairlie (2003) put forward arguments that relate to rational behavior, as well as 'irrational preferences'. The previous point builds on the view that teachers may have to focus more on children that require special attention, so that overall educational standards might fall as more immigrant children enter the class. ${ }^{8}$ A similar argument would be that more school resources have to be directed towards immigrant groups. Also, a school's ethnic composition might work as an indicator for school quality when there are no other easily accessible measures at hand, such as test scores. In case there would be more objective information on school quality, the

\footnotetext{
${ }^{7}$ Their results point to sorting along socioeconomic lines, however, they do not find improvements in various outcome variables on school achievements (sorting along ethnic lines is not addressed). Their results are consistent with Cullen et al. (2005), who look at the outcome of 'open enrolment rules' into Chicago public schools. A recent study by Böhlmark and Lindahl (2007) looks at the effect of the introduction of free schools in Sweden in 1992. There main focus is on educational outcomes, but they also report results on sorting. They find a positive correlation between the fraction of immigrants in a municipality and enrollment into free schools, i.e. pupils with immigrant background show a larger propensity to enroll into such schools than native Swedes.

${ }^{8}$ A study by Gould, Lavy and Paserman (2009) states a negative effect as to the presence of immigrants in elementary schools for the chances of passing matriculation exams in Israel. Other studies that have looked at the interplay of ethnic heterogeneity and school performance did not find similar negative correlations; see e.g. Angrist and Lang (2004) and Guryan (2004).
} 
importance of ethnic diversity might receive less weight, as claimed by Tedin and Weiher (2004).

The paper unfolds as follows. In the next section I discuss some aspects regarding the Danish school system, especially the institutional set-up of its free school system. This is followed by a theoretic discussion on measuring private school attendance rate on the aggregated level, as well as some descriptives on school choice. Section 4 presents the data and the outcomes from regression estimations. Section 5 concludes.

\section{The Danish (free) school system}

Denmark applies a system of nine years of compulsory education (i.e. not compulsory schooling), for everyone in the age group 6-16. By default, children are assigned to a 'folkeskole', i.e. the local primary and lower secondary school. A special feature of the Danish educational system is the possibility of attending a tenth form subsequent to nine years of compulsory education. One motive for attending another year at the elementary school is to get more time to prepare for upper secondary education. ${ }^{9}$ The upper secondary education system includes both academically oriented programs for students that want to continue to higher education, as well as vocationally oriented programs for those who intend to enter the labor market after finishing nine years of compulsory school.

\footnotetext{
${ }^{9}$ This option has been used by about $58 \%$ in (1992) to $37 \%$ (in 2004) of the students leaving grade 9 . A small number of schools also offer an 11th grade option. Besides, pupils aged 14 to 18 can attend so called "continuation schools" (efterskole), i.e. schools that aim to build a bridge from elementary schools to secondary education, and which "enjoy complete freedom of curriculum," see Johnson (1997). These schools are not included in the estimations. For a more detailed description of the educational system in Denmark see Danish Ministry of Foreign Affairs (2008).
} 
One way of implementing school choice is to fund schools based on the actual number of pupils enrolled. In practice, such a system can be realized by introducing school vouchers, i.e. a fixed amount of public money is paid to schools for each pupil enrolled. In a more 'openmarket' version, both public and privately operated schools compete with each other. For example, such a system has been applied in Sweden since the early 1990s. In Denmark, on the other hand, until 2004 pupils were assigned to the public school nearest to their home. In theory parents could apply for other public schools, but such requests had to find approval by local authorities and the schools concerned. However, during all years there has been the option of registering children to a privately operated school. In the Danish context the notion 'private schools' generally refers to so called 'free schools' (friskole). These schools are granted state allowances, but are operated by private entities, such as parent cooperatives, parties, religious groups or other non-governmental organizations. ${ }^{10}$ To some extent free schools are comparable to charter schools, yet there are some distinct differences. ${ }^{11}$ First, in contrast to charter schools, free schools levy a fee of ca $15-20 \%$ of the educational cost on the parents. Second, free schools have been a real option over several decades across the whole country and are a well-established feature of the Danish school system, offering a large variety of educational programs to choose from. As can be seen from Table A1 in appendix, the use of free schools has been rather common irrespective of municipality size. Also, in contrast to charter schools, free schools are allowed to choose among its applicants, according to Andersen (2008).

\footnotetext{
${ }^{10}$ There are a small number of private schools that mainly rely on tuition fees, but they only make a minor feature of the Danish educational system, so the focus in this study is on free schools.

${ }^{11}$ For more details and an account of studies on charter schools see Hanushek et al. (2007). They describe charter schools as “...hybrids of public and private institutions that allow independent development and decision-making along with public financing and state accountability for performance" (p. 824). In contrast to private schools, minority groups, especially Afro-Americans, are over-represented in charter schools.
} 
On two major accounts the Danish education system comply with standard requirements for free school choice. First, there is a non-means tested alternative to public schools; second, the school boards are given leeway in the way they tend to accomplish the prescribed educational objectives. Vouchers are granted on a universal base and enrolment to free schools is not restricted by municipal boundaries. In praxis, this means that free schools are largely financed by state government grants, i.e. about 80 to $85 \%$ of costs are state funded, while the remaining amount is financed by tuition fees paid by the parents. ${ }^{12}$ As a result free schools are an affordable alternative for a larger part of the population. There are several restrictions and requirements for running free schools. According to the Ministry of Education (2008), there have to be a certain number of pupils (at least twelve) enrolled in all grades from 1 to 7 , and free schools "must not be owned by a private individual or run for private profit." There also are certain obligations in terms of quality standards, especially as to teaching in Danish, English and mathematics, which has to comply with demands set by the central government, similar as those applying for public schools. While free schools are funded according to the number of pupils enrolled, public schools regularly do not have their budget tied to the number of pupils. ${ }^{13}$

The long tradition of providing a "de facto voucher system" in Denmark has attracted some research on the relative advantage/disadvantage of private versus public schooling in terms of educational performance. Andersen (2008), using data for 2003, found that overall there are

\footnotetext{
${ }^{12}$ In 2006 the operational costs paid by the state government amounted to $41,000 \mathrm{dkr}$ (per year), and the fee paid by the parents was $9,000 \mathrm{dkr}$ on average. The local governments reimbursed the state by paying $31,000 \mathrm{dkr}$ for each pupil. See "Private Schools in Denmark," Danish Ministry of Education, http://www.eng.uvm.dk/

${ }^{13}$ According to Andersen (2008), some municipalities apply a formal rule of funding public schools according to the number of pupils enrolled, but in praxis this does not seem to be a very strictly administered policy.
} 
no significant advantages for pupils attending private over public schools. ${ }^{14}$ Actually, if one takes account of socio-economic status, pupils attending free schools had inferior educational outcomes regarding examination scores in mathematics and written Danish than comparable groups attending public schools. One explanation for that result holds that parents choose free schools for other reasons than scholarly quality, for example on the grounds of religious affiliation. A related study by Schindler Rangvid (2009) addresses the issue of 'native flight'. As Andersen (2008) she uses individual data for the year 2003. Focusing at the school level within the region of Copenhagen, her results point to that native Danes are more likely to opt out local public schools the larger the share of pupils with immigrant background in the school district. This holds true even after controlling for family, municipality and school characteristics, such as parents' education, test scores and teacher/student ratios.

\section{Conceptual framework and descriptives}

In this section I aim to exemplify how immigration could affect private school attendance rates by means of a simple model. It looks at the outcomes of processes, rather than discussing the mechanism underlying them. Due to its straightforward comparative static predictions, the model provides a base of reference for subsequent empirical estimations.

Starting by defining the immigration share $i$ and $n$ as the number of immigrants and native born students respectively divided by the population (defined as immigrants plus native born), the overall attendance rate $a$ for private schools can be characterized as the sum of the attendance rate for both groups as follows

$$
a=a_{n} n+a_{i} i=a_{n}(1-i)+a_{i} i
$$

\footnotetext{
${ }^{14}$ Other studies on the effect of private school on educational achievements in Denmark draw similar conclusions; see Nannestad, 2004, and Schindler Rangvid, 2008.
} 
Here the sub-index demarcates attendance rates for natives and immigrants respectively. From

(i) one can determine the marginal impact of immigration on the overall attendance rate

$\frac{\partial a}{\partial i}=a_{i}-a_{n} \Rightarrow\left[\frac{\partial a}{\partial i} \frac{i}{a}\right]=\varepsilon_{i}^{a}=\frac{\left(a_{i}-a_{n}\right) i}{a_{n} n+a_{i} i}=\frac{a_{i} i-a_{n} i}{a_{n}(1-i)+a_{i} i}=\frac{a_{i} i-a_{n} i}{a_{i} i-a_{n} i+a_{n}}=1-\frac{a_{n}}{a_{n} n+a_{i} i}$

$$
\varepsilon_{i}^{a}=1-\frac{a_{n}}{a_{n} n+a_{i} i}
$$

Equation (ii) states the elasticity of private schools attendance with respect to the immigration rate. As a next step, let's consider the relative attendance rate across groups to be linear as follows

$$
a_{i}=k a_{n}
$$

This is saying that the average attendance rate for pupils with immigrant background is assumed to be $k$ times that for pupils of native descent. Combining (ii) and (iii) one receives the following:

$$
\varepsilon_{i}^{a}=1-\frac{a_{n}}{a_{n} n+k a_{n} i}=1-\frac{1}{n+k i}=1-\frac{1}{1-i+k i}=1-\frac{1}{1+i(k-1)}
$$

The last relation allows for some simple comparative static results. In case the attendance rate is similar across groups, i.e. $k=1$, then $\varepsilon_{i}^{a}=0$, saying that there is no change in the overall attendance rate irrespective of the size in immigration share $i$. On the other hand, if $k>1[k<1]$, then $\varepsilon_{i}^{a}>0\left[\varepsilon_{i}^{a}<0\right]$, saying that overall attendance rate for private education would increase [decrease] by an increase in $i$, following a change in the demographic composition across municipalities. In the next subsection I look at empirical evidence on the size of $k$.

\subsection{Summary statistics on private school attendance rate}

To attain an understanding on the size of the relative attendance rate $k$ in Table 1 , mean values as to attendance ratios for pupils with native Danish parents and for pupils with parents from countries outside the Western hemisphere are shown. The numbers only include children in 
schools from grade 8 to grade 11, i.e. pupils attending upper primary/lower secondary education. As already pointed out in Section 2, grade 10 and 11 are optional. ${ }^{15}$ As regression estimations in this study are based on figures relating to the municipality level, summary statistics are calculated by taking each municipality as one observation. For comparison also figures on the individual level are shown. When comparing figures on the individual and municipality level the differences are larger for pupils with immigrant background. To certain extent this outcome is caused by the fact that many children of foreign background are living in major city areas. ${ }^{16}$

The propensity of attending a private school for pupils of immigrant descent is about 0.37 to 0.8 times that of pupils with native Danish background, varying by year and level of comparison; see the two rows noted by $k$ in Table 1 . There clearly is an increasing trend in private school attendance rates as regards native Danes. This holds true both at the municipality as well as the individual level, while it is about constant on the individual level among children originating from countries outside Western-Europe and OECD countries, and decreasing on the municipality level. The latter could be explained by the placement of newly arriving refugees in smaller municipalities. In particular, the significant drop in private school attendance rates on the municipality level that took place between the years 1993 and 1996 (see panel B, first row) could to some extent be caused by the influx of a large group of

\footnotetext{
${ }^{15}$ Betts and Fairlie (2003) make a distinction on pupils attending high schools and those in elementary schools. They argue that the impact of immigration should be larger in high schools, as elementary schools are covering smaller residential districts, i.e. parents can easier ensure their preferred peer groups due to residential segregation. Differences in the number of school districts at the primary and secondary level have been utilized by Urqiola (2005), for the purpose of disentangling mechanisms of socioeconomic and/or racial stratification.

${ }^{16}$ By calculating mean values on the municipality level, larger cities receive less weight than what their population size would imply.
} 
refugees from Bosnia-Herzegovina that were placed in 1994 and 1995. See next Section for a discussion of the placement policy in Denmark.

Table 1. Attendance in private schools in relation to public schools

\begin{tabular}{|c|c|c|c|c|c|c|}
\hline & 1990 & 1993 & 1996 & 1999 & 2002 & 2005 \\
\hline & \multicolumn{6}{|c|}{ Panel A } \\
\hline & \multicolumn{6}{|c|}{ Private school attendance rate over the whole of Denmark. Individual level } \\
\hline \multicolumn{7}{|l|}{ Children with parents } \\
\hline \multicolumn{7}{|l|}{ from countries } \\
\hline outside Western- & 0.094 & 0.085 & 0.097 & 0.104 & 0.095 & 0.096 \\
\hline \multicolumn{7}{|l|}{ Europe and OECD } \\
\hline \multicolumn{7}{|l|}{ countries } \\
\hline \multicolumn{7}{|l|}{ Children with native } \\
\hline Danish parents & 0.124 & 0.132 & 0.144 & 0.151 & 0.152 & 0.159 \\
\hline \multirow[t]{3}{*}{$k$} & 0.757 & 0.647 & 0.673 & 0.690 & 0.622 & 0.603 \\
\hline & \multicolumn{6}{|c|}{ Panel B } \\
\hline & \multicolumn{6}{|c|}{ Private school attendance rate over the whole of Denmark. Municipality level } \\
\hline \multirow{2}{*}{\multicolumn{7}{|c|}{$\begin{array}{l}\text { Children with parents } \\
\text { from countries }\end{array}$}} \\
\hline & & & & & & \\
\hline outside Western- & 0.085 & 0.078 & 0.057 & 0.056 & 0.052 & 0.056 \\
\hline \multicolumn{7}{|l|}{ Europe and OECD } \\
\hline \multicolumn{7}{|l|}{ countries } \\
\hline \multicolumn{7}{|l|}{ Children with native } \\
\hline Danish parents & 0.106 & 0.117 & 0.131 & 0.139 & 0.140 & 0.151 \\
\hline$k$ & 0.797 & 0.670 & 0.435 & 0.403 & 0.374 & 0.370 \\
\hline
\end{tabular}

Note: Figures calculated according to Denmark Statistics: U19. Calculations based on the number of pupils enrolled in grade 8 to 11 . Pupils enrolled in efterskole are not included.

As can be seen from Figure 1, the relative size of the share $i$ differs significantly with respect to municipality size. As emanates from equation (iv), the larger is $i$, the more negative is the elasticity $\varepsilon_{i}^{a}$, given that $k<1 .{ }^{17}$ If one compares the relative changes over time over

\footnotetext{
${ }^{17}$ For 2005 the ratio $k$ is .34 for smaller municipalities, .35 for medium sized municipalities and about .50 for larger municipalities. The private school attendance rates in the same year for immigrants (i.e. $a_{i}$ ) reads $.05, .05$ and .085 respectively. There is considerable variation across municipalities. For example, for the city of
} 
municipalities as shown in Figure 1, the long term increase occurs to be slightly steeper for municipalities with more than 20 thousand inhabitants, while the path of change looks rather similar for medium sized and smaller municipalities.

\section{Figure 1.}

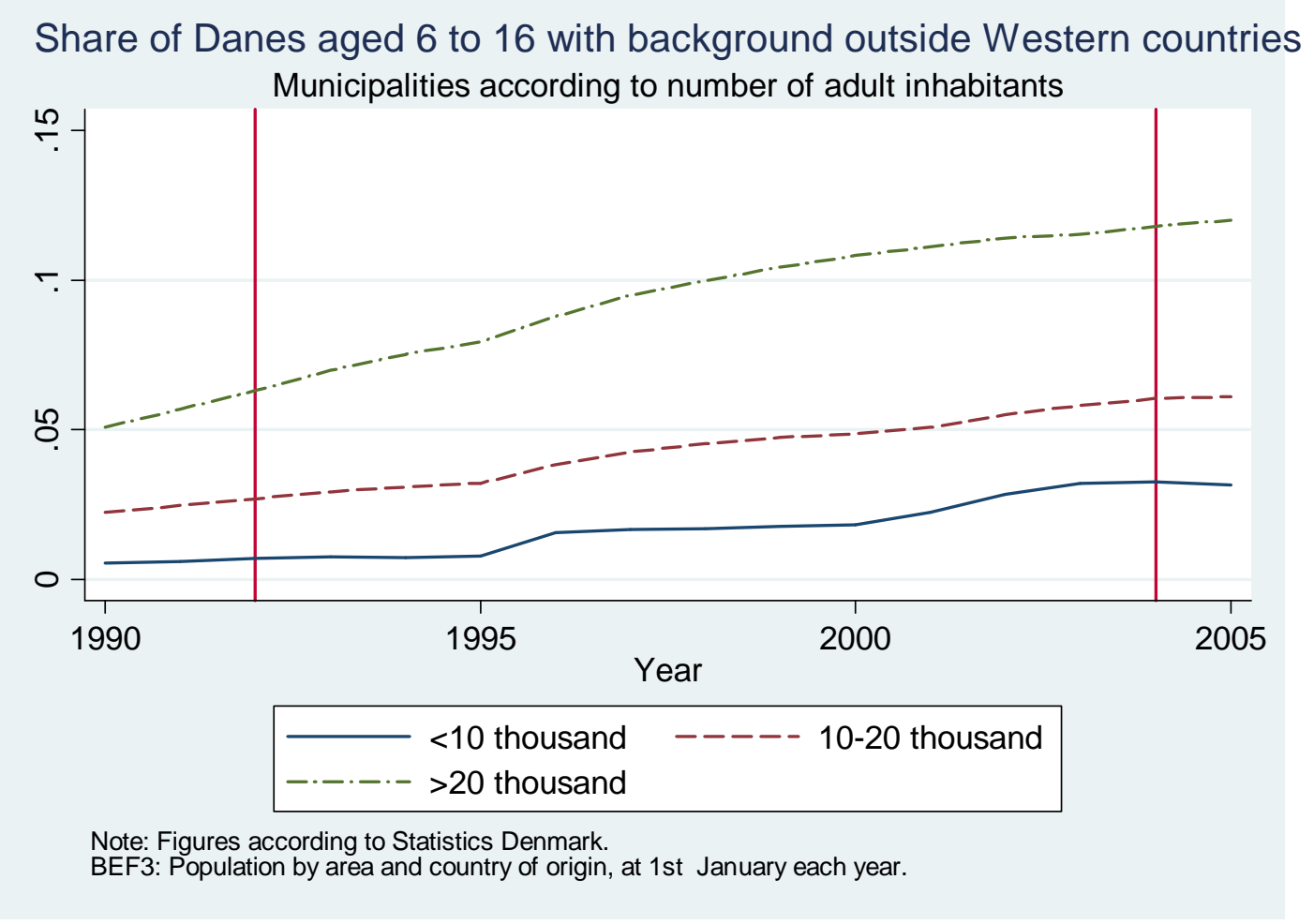

Irrespective of municipality size, there clearly is an increase in the minority group share over time. This implies that given the private school attendance patterns outlined above, one should expect to find a negative effect on overall private school attendance rate as a result of a demographic change in the local population following from an influx of pupils of foreign origin. In contrast, if the estimated elasticity of private school attendance with respect to immigration is positive, that would indicate a change in the inclination to attend private

Copenhagen the average private school attendance rate is about 0.27 and 0.15 for native Danes and those of foreign descendent, respectively. 
schools by itself. Actually, from Table 1 one can see that there is a small, but consistently increasing trend in private school attendance rate for children with native Danish parents over the period 1992 to 2004 . In the regression estimations the elasticity $\varepsilon_{i}^{a}$ will be estimated for the total attendance rate according to equation (ii), as well as separately for native Danes and children with immigrant background from countries outside the EU and OECD. A number of covariates are included to disclose the net impact of a larger share of pupils with immigrant background on school choice. Stated more formally, in case estimations reveal a positive elasticity $\varepsilon_{i}^{a}$ this would indicate a relation as follows

$$
a_{n}=f(i), f^{\prime}(i)>0 \Rightarrow \frac{\partial a_{n}}{\partial i}>0
$$

\section{Data and Estimations}

The data used for this study is provided by Statistics Denmark. It includes detailed information on the socio-economic and demographic situation across municipalities. The estimations in the baseline set up will include all Danish municipalities over the period 1992 to 2004. During that period there have been a total of 275 municipalities in Denmark, distributed over 14 counties.

In their study Betts and Fairlie (2003) are controlling for school quality by making use of two measures, i.e. public school expenditures per pupil (in the metropolitan area) and pupil/teacher ratio in public and private schools (on the state level), respectively. As for the present study there is no information on pupil/teacher ratios, while public school expenditures per pupil have been imputed base on municipality expenditure for public schools (folkeskole), see note to Table A1 in appendix. In addition, I include local tax rate as covariate as an 
approximation for municipalities' position on education. ${ }^{18}$ In subsequent estimations prices for single-family houses are included. This addresses that public school quality could be capitalized in house values, see Brunner and Imazeki (2008), and Cellini et al. (2008) for studies discussing such mechanisms. Yet, in case immigration has a direct effect on house prices, this would define another path by which immigration might affect private school attendance rates. ${ }^{19}$ Controls for income and unemployment rates are included to address that in less prosperous regions the demand for private schooling might be lower. Other controls regards average education level within municipalities as households with a higher education level have shown to be more inclined to opt for private schools, see e.g. Betts and Fairlie (2001). To hold constant for common time trends year dummies are included, while structural differences across municipalities enter the regression model by means of municipality fixedeffects. For example, these account for differences in access to local transport facilities, proximity to institutions of higher education, or even the size of the local religious community.

\subsection{Immigration and placement of refugees into Danish municipalities}

With the arrival of a wave of immigrants at the beginning of the $1980 \mathrm{~s}$, public authorities experienced problems in providing refugees with appropriate accommodation. For that reason a placement policy was introduced in 1986 according to which new arrivals were to be

\footnotetext{
${ }^{18}$ The Danish governmental system grants considerably leeway to local governments to decide on local tax rates and the way tax money is spent. Education accounts for a main part in the local budgets; see e.g. Gerdes (2009).

${ }^{19}$ The effect of immigration on housing prices is still open to debate. For references on some studies done for the US, see Card (2007). A study by Bayer et al. (2007) concludes that race is not capitalized in housing prices as sorting based on race would be sufficient to satisfy "self-segregating preferences."
} 
dispersed over the whole of Denmark. ${ }^{20}$ It was intended to counteract the tendency of immigrants to move to metropolitan areas. By and large, the policy led to that refugees were distributed to large and medium-sized municipalities. From 1995, as a consequence of the large influx of refugees from Bosnia-Herzegovina, the main criterion for assigning refugees became availability of housing. This policy change resulted in that also smaller municipalities were forced to accept refugees. From Figure 1 one can see the distinct increase in the share of children with parents originating from countries outside the Western hemisphere that took place in 1995/1996. Most pronounced is the effect in smaller-size municipalities. Once they had been granted asylum, refugees were free to move wherever they wanted. However, there were incentives not to change the initial location, at least not before completing an 18-month 'introductory period'. Refugees complying with the policy could expect help from local authorities in finding appropriate housing and child day care. From January 1999 the dispersal policy became more restrictive as refugees risked losing the special 'introduction allowance' - a form of social assistance benefit - if they decided to move within a three-year period. Examination of the pre-1999 placement policy found that about half of the placed refugees chose to stay, while the other half moved further to another municipality, preferably to areas with a higher proportion of their countrymen; see Damm (2009). Her results point to that younger, single persons were most likely to move from the assigned municipality. On the municipality level, the most important factors for the decision to move or not were the proportion of co-nationals, population size, unemployment rates and access to public housing across municipalities. $^{21}$

\footnotetext{
${ }^{20}$ For more information regarding the way the placement policy was accomplished see Gerdes (2009) and references given there.

${ }^{21}$ Access to private schools across municipalities has not been considered as a factor in placement of refugees.
} 


\subsection{Results}

Estimations are done in a log-log setting, which allows stating a relation of dependent and independent variables in elasticities, thereby connecting to the model outlined in Section 3. Municipality fixed-effects are controlled for by applying within transformation of variables. As every municipality is treated as one educational market, no weights are used here, following the example of Hsieh and Urquiola (2006). ${ }^{22}$ The model reads as follows:

$$
\ln \left(a_{m t}\right)-\overline{\ln \left(a_{m .}\right)}=\gamma^{\prime}\left[x_{m t}-\bar{x}_{m .}\right]+\beta\left[\ln S_{m t}-\overline{\ln \left(S_{m .}\right)}\right]+\left(e_{m t}-\bar{e}_{m .}\right), \text { with } e_{m t} \sim \operatorname{IID}\left(0, \sigma_{e}^{2}\right) .
$$

The dependent variable $a_{m t}$ states the private schools attendance rate in municipality $m$ in year $t, x_{m t}$ are covariates and $S_{m t}$ is the share of pupils of age 6-16 with parents from countries outside Western Europe and OECD countries. ${ }^{23}$ As to the definition of the dependent variable, it is based on the number of children from each municipality attending a free school within or outside the municipality they were living. The identifying assumption in measuring the effect of a change in demographic composition within municipalities on private school attendance rates is that all relevant aspects determining the outcome variable are caught by the included covariates, so that the condition on observable assumption applies, saying that $E\left[S_{m t} e_{m t} \mid X_{m t}\right]=0$. One concern regards endogeneity of the variable of interest, i.e. the bias that would occur if households chose to move to another municipality for the purpose of enrolling their children to schools with preferred peer groups, see e.g. Ladd (2002) and Bifulco et al. (2009). To address such concerns, in some estimations (not shown) the number of children in the age group 6 to 16 that left a municipality in each year has been included as additional covariate. Overall, such a control did not have any significant impact.

\footnotetext{
${ }^{22}$ In appendix results form estimations weighted for population size are shown, see Table A3.

${ }^{23}$ This is about similar to the age group used in Betts and Fairlie (2003), i.e. they use as their measure of immigration pupils aged 7-16. They motivate this choice by the fact that redistribution of school resources due to immigration will affect all grades, even those attending high school.
} 
At the outset, elasticities are presented where all municipalities enter into the model, see columns (1) to (4) in the following tables. For the purpose of allowing for a closer view on underlying mechanisms, in columns (5) to (7) estimations are subdivided with respect to the population size of municipalities. ${ }^{24}$ In the appendix changes in variables for the years 1992 to 2004 are shown.

The results in Table 2 reveal positive elasticities, indicating a rise of 2.5 to $4.5 \%$ in the share attending free schools when doubling the share of pupils of foreign descendent; see columns (1) to (4). Comparing column (1) and (2) in Table 2, the coefficient regarding the share of children from countries outside the EU and OECD is somewhat affected by inclusion of covariates such as unemployment rates, local tax rates, public school expenditures, population size and the share of people with higher education, but it is still significantly positive. When including a control for house prices in the municipalities, see column (3), the impact of a change in the share of migrants on private school attendance rates becomes somewhat smaller and insignificant. The latter result could be due to that house prices might be affected by immigration. As another measure to test for omitted variables that might affect the estimate of interest, controls for regional specific time trends have been included. Among others, such a test can be motivated by the fact that policies regarding upper secondary education are settled on the regional level. In the estimations such controls are created by interacting 14 regional dummies with 13 year dummies. As can be seen from Table 2, column (4), extending the model in such a way has some impact, not the least on the coefficient estimates regarding

\footnotetext{
${ }^{24}$ All standard errors are robust to arbitrary within-municipality serial correlation and heteroskedasticity. Included covariates are weakly dependent, i.e. correlation diminishes over time. In such situation fixed effects are preferred to first difference estimations. See Wooldridge (2002), p. 302 for a discussion.
} 
housing prices. However, the coefficient estimate as to the share of pupils from countries outside Western Europe or OECD increases.

Table 2. Dependent variable: Log of private school attendance rate

\begin{tabular}{|c|c|c|c|c|c|c|c|}
\hline & (1) & (2) & (3) & (4) & (5) & (6) & (7) \\
\hline & All & All & All & All & Small & Medium & Large \\
\hline $\begin{array}{l}\text { Log share of } \\
\text { immigrant children } \\
\text { aged 6-16 }\end{array}$ & $\begin{array}{c}0.0458 \\
(0.0181)^{*} \\
*\end{array}$ & $\begin{array}{c}0.0331 \\
(0.0181)^{*}\end{array}$ & $\begin{array}{c}0.0249 \\
(0.0178)\end{array}$ & $\begin{array}{c}0.0343 \\
(0.0187) *\end{array}$ & $\begin{array}{c}0.0292 \\
(0.0221)\end{array}$ & $\begin{array}{c}0.0491 \\
(0.0488)\end{array}$ & $\begin{array}{c}-0.0290 \\
(0.0923)\end{array}$ \\
\hline $\begin{array}{l}\text { Log unemployment } \\
\text { rate }\end{array}$ & & $\begin{array}{l}-0.0800 \\
(0.0627)\end{array}$ & $\begin{array}{l}-0.1041 \\
(0.0643)\end{array}$ & $\begin{array}{l}-0.0326 \\
(0.0702)\end{array}$ & $\begin{array}{c}-0.0471 \\
(0.0878)\end{array}$ & $\begin{array}{l}-0.0152 \\
(0.1440)\end{array}$ & $\begin{array}{c}0.0018 \\
(0.0876)\end{array}$ \\
\hline Log income & & $\begin{array}{c}1.3437 \\
(0.4851)^{*} \\
* *\end{array}$ & $\begin{array}{c}1.3291 \\
(0.4845)^{*} \\
* *\end{array}$ & $\begin{array}{c}0.9409 \\
(0.4693)^{*} \\
*\end{array}$ & $\begin{array}{c}0.2924 \\
(0.6997)\end{array}$ & $\begin{array}{c}0.5614 \\
(0.9765)\end{array}$ & $\begin{array}{c}0.7929 \\
(0.8579)\end{array}$ \\
\hline $\begin{array}{l}\text { Log local income } \\
\text { tax }\end{array}$ & & $\begin{array}{c}0.4889 \\
(0.5107)\end{array}$ & $\begin{array}{c}0.3567 \\
(0.5036)\end{array}$ & $\begin{array}{c}-0.5041 \\
(0.5598)\end{array}$ & $\begin{array}{c}-0.1049 \\
(0.9419)\end{array}$ & $\begin{array}{c}-1.6865 \\
(0.9148)^{*}\end{array}$ & $\begin{array}{c}-1.0283 \\
(0.7493)\end{array}$ \\
\hline $\begin{array}{l}\text { Log public school } \\
\text { expenditure /pupil }\end{array}$ & & $\begin{array}{c}0.4482 \\
(0.1847)^{*} \\
*\end{array}$ & $\begin{array}{c}0.4375 \\
(0.1828)^{*} \\
*\end{array}$ & $\begin{array}{c}0.3821 \\
(0.1824)^{*} \\
*\end{array}$ & $\begin{array}{c}0.8459 \\
(0.1671)^{*} \\
* *\end{array}$ & $\begin{array}{c}0.4452 \\
(0.1326)^{*} \\
* *\end{array}$ & $\begin{array}{c}0.1686 \\
(0.2096)\end{array}$ \\
\hline Log adult population & & $\begin{array}{c}-1.2934 \\
(0.7109)^{*}\end{array}$ & $\begin{array}{c}-0.9072 \\
(0.7162)\end{array}$ & $\begin{array}{c}-0.9085 \\
(0.7883)\end{array}$ & $\begin{array}{l}-0.1719 \\
(0.9946)\end{array}$ & $\begin{array}{c}-4.5227 \\
(2.2533)^{*} \\
*\end{array}$ & $\begin{array}{c}-1.8495 \\
(1.7236)\end{array}$ \\
\hline $\begin{array}{l}\text { Log share of higher } \\
\text { educated }\end{array}$ & & $\begin{array}{c}-0.5531 \\
(0.3630)\end{array}$ & $\begin{array}{c}-0.5459 \\
(0.3687)\end{array}$ & $\begin{array}{c}-0.1611 \\
(0.3919)\end{array}$ & $\begin{array}{c}0.3911 \\
(0.5162)\end{array}$ & $\begin{array}{c}0.2063 \\
(0.6804)\end{array}$ & $\begin{array}{c}-0.5157 \\
(0.7385)\end{array}$ \\
\hline Log housing prices & & & $\begin{array}{c}-0.2701 \\
(0.1322)^{*} \\
*\end{array}$ & $\begin{array}{c}-0.0528 \\
(0.1390)\end{array}$ & $\begin{array}{l}-0.0959 \\
(0.1622)\end{array}$ & $\begin{array}{c}-0.3340 \\
(0.4129)\end{array}$ & $\begin{array}{c}0.3957 \\
(0.3523)\end{array}$ \\
\hline $\begin{array}{l}\text { Regional trends } \\
\text { included }\end{array}$ & No & No & No & Yes & Yes & Yes & Yes \\
\hline Observations & 3378 & 3378 & 3373 & 3373 & 2116 & 685 & 572 \\
\hline \# of municipalities & 275 & 275 & 275 & 275 & 178 & 53 & 44 \\
\hline R-squared & 0.070 & 0.090 & 0.093 & 0.241 & 0.255 & 0.486 & 0.481 \\
\hline
\end{tabular}

Note: Clustered standard errors in parentheses. ${ }^{*}$ significant at $10 \% ; * *$ significant at $5 \% ; * * *$ significant at $1 \%$.

All estimations control for municipality fixed effects and include time dummies.

When looking at the smaller municipalities, i.e. those with less than 10 thousand inhabitants, see column (5), the coefficient becomes somewhat smaller than in the overall sample. Results are somewhat different if one turns to medium sized municipalities, as can be seen from column (6). Here the effect of immigration on private school attendance rate becomes larger. 
For municipalities with more than 20 thousand inhabitants the elasticity turns out negative, see column (7). The approach for this analysis is to treat every municipality as one educational market. As a sensitivity test, Table A3 in appendix shows estimations when estimations are weighted by population size, overall revealing elasticities slightly larger than in the baseline set-up shown in Table 2.

Table 3. Dependent variable: Log of private school attendance rate. Pupils with parents born in Denmark

\begin{tabular}{|c|c|c|c|c|c|c|c|}
\hline & (1) & (2) & (3) & (4) & (5) & (6) & (7) \\
\hline & All & All & All & All & Small & Medium & Large \\
\hline $\begin{array}{l}\text { Log share of } \\
\text { immigrant children } \\
\text { aged 6-16 }\end{array}$ & $\begin{array}{c}0.0506 \\
(0.0182)^{*} \\
* *\end{array}$ & $\begin{array}{c}0.0382 \\
(0.0181)^{*} \\
*\end{array}$ & $\begin{array}{c}0.0300 \\
(0.0178)^{*}\end{array}$ & $\begin{array}{c}0.0387 \\
(0.0187)^{*} \\
*\end{array}$ & $\begin{array}{c}0.0350 \\
(0.0221)\end{array}$ & $\begin{array}{c}0.0512 \\
(0.0479)\end{array}$ & $\begin{array}{r}-0.0501 \\
(0.0928)\end{array}$ \\
\hline $\begin{array}{l}\text { Log unemployment } \\
\text { rate }\end{array}$ & & $\begin{array}{l}-0.0864 \\
(0.0618)\end{array}$ & $\begin{array}{c}-0.1103 \\
(0.0634)^{*}\end{array}$ & $\begin{array}{l}-0.0402 \\
(0.0693)\end{array}$ & $\begin{array}{l}-0.0525 \\
(0.0866)\end{array}$ & $\begin{array}{l}-0.0193 \\
(0.1434)\end{array}$ & $\begin{array}{l}-0.0137 \\
(0.0793)\end{array}$ \\
\hline Log income & & $\begin{array}{c}1.2627 \\
(0.4857)^{*} \\
* *\end{array}$ & $\begin{array}{c}1.2455 \\
(0.4845)^{*} \\
*\end{array}$ & $\begin{array}{c}0.8184 \\
(0.4639)^{*}\end{array}$ & $\begin{array}{c}0.2090 \\
(0.6960)\end{array}$ & $\begin{array}{c}0.5304 \\
(0.9813)\end{array}$ & $\begin{array}{c}0.7010 \\
(0.8908)\end{array}$ \\
\hline $\begin{array}{l}\text { Log local income } \\
\text { tax }\end{array}$ & & $\begin{array}{c}0.5463 \\
(0.5115)\end{array}$ & $\begin{array}{c}0.4123 \\
(0.5048)\end{array}$ & $\begin{array}{l}-0.4348 \\
(0.5579)\end{array}$ & $\begin{array}{l}-0.0699 \\
(0.9404)\end{array}$ & $\begin{array}{c}-1.7764 \\
(0.9437)^{*}\end{array}$ & $\begin{array}{c}-0.5221 \\
(0.7693)\end{array}$ \\
\hline $\begin{array}{l}\text { Log public school } \\
\text { expenditure /pupil }\end{array}$ & & $\begin{array}{c}0.4256 \\
(0.1854)^{*} \\
*\end{array}$ & $\begin{array}{c}0.4148 \\
(0.1834)^{*} \\
*\end{array}$ & $\begin{array}{c}0.3561 \\
(0.1826)^{*}\end{array}$ & $\begin{array}{c}0.8326 \\
(0.1689)^{*} \\
* *\end{array}$ & $\begin{array}{c}0.3758 \\
(0.1520)^{*} \\
*\end{array}$ & $\begin{array}{c}0.1263 \\
(0.1878)\end{array}$ \\
\hline Log adult population & & $\begin{array}{c}-1.3463 \\
(0.7069)^{*}\end{array}$ & $\begin{array}{l}-0.9611 \\
(0.7082)\end{array}$ & $\begin{array}{l}-0.9986 \\
(0.7807)\end{array}$ & $\begin{array}{l}-0.4041 \\
(0.9857)\end{array}$ & $\begin{array}{c}-4.6669 \\
(2.2667)^{*} \\
*\end{array}$ & $\begin{array}{l}-0.7357 \\
(1.6556)\end{array}$ \\
\hline $\begin{array}{l}\text { Log share of higher } \\
\text { educated }\end{array}$ & & $\begin{array}{l}-0.5097 \\
(0.3614)\end{array}$ & $\begin{array}{l}-0.5002 \\
(0.3666)\end{array}$ & $\begin{array}{l}-0.1115 \\
(0.3869)\end{array}$ & $\begin{array}{c}0.4239 \\
(0.5072)\end{array}$ & $\begin{array}{c}0.2727 \\
(0.7015)\end{array}$ & $\begin{array}{l}-0.6675 \\
(0.7188)\end{array}$ \\
\hline Log housing prices & & & $\begin{array}{c}-0.2699 \\
(0.1312)^{*} \\
*\end{array}$ & $\begin{array}{l}-0.0602 \\
(0.1399)\end{array}$ & $\begin{array}{l}-0.1013 \\
(0.1650)\end{array}$ & $\begin{array}{l}-0.3351 \\
(0.4095)\end{array}$ & $\begin{array}{c}0.2590 \\
(0.4008)\end{array}$ \\
\hline $\begin{array}{l}\text { Regional trends } \\
\text { included }\end{array}$ & No & No & No & Yes & Yes & Yes & Yes \\
\hline Observations & 3376 & 3376 & 3371 & 3371 & 2114 & 685 & 572 \\
\hline \# of municipalities & 275 & 275 & 275 & 275 & 178 & 53 & 44 \\
\hline R-squared & 0.084 & 0.105 & 0.107 & 0.259 & 0.272 & 0.494 & 0.495 \\
\hline
\end{tabular}

Note: Clustered standard errors in parentheses. $*$ significant at $10 \% ; * *$ significant at 5\%; *** significant at $1 \%$. All estimations control for municipality fixed effects and include time dummies. 
Table 3 and Table 4 present results separately for children with native born parents and children of foreign ancestry. For the group of pupils with native born parents (see Table 3), the results are rather similar to those found for the aggregated group in Table 2. Overall the coefficient for the share of children aged 6-16 from countries outside the Western hemisphere are larger in Table 3 than in Table 2, while it becomes smaller (i.e. more negative) for municipalities with more than 20 thousand inhabitants.

The results for the group of pupils with parents from countries outside the EU and OECD are rather different, see Table 4. An influx of pupils aged 6-16 of foreign origin leads to a considerable decrease in private school attendance rates. The explanation closest at hand is that newly immigrated children by default were put into public rather than free schools at time of arrival. In addition, as most of the newly arrived refugees had rather low incomes, frequently made up of means tested social assistance, free schools have been out of reach even if they would have been a preferred choice. The reduced number of observations (i.e. municipalities) in Table 4 is due to the fact that in several (smaller) municipalities either there are no children of foreign descendent attending grade 8 to grade 11 , or they did not attend free schools so that the dependent variable becomes a missing value due to the logarithmic transformation. $^{25}$

\footnotetext{
${ }^{25}$ This implies that sample selection is likely to confound results presented in Table 4. As the results for the group of pupils with immigrant background are not a main issue in this study, I will not address such aspects in the remainder of the paper. As to estimations in Table 2 and Table 3 there also is a reduction of observations due to missing values in one or several variables, i.e. the panel underlying the estimations is not balanced. In sensitivity estimation a dummy variable has been included taking the value one if that municipality has been missing for some year(s). Such a control did not have any major impact on the variable of interest. As another falsification test, the current value as to the share of immigrant pupils in a municipality has been substituted by subsequent year's equivalence. The coefficient estimates loose in power and significance, which strengthens that
} 
Table 4. Dependent variable: Log of private school attendance rate. Pupils with parents from countries outside the EU and OECD

\begin{tabular}{|c|c|c|c|c|c|c|c|}
\hline & (1) & (2) & (3) & (4) & (5) & (6) & (7) \\
\hline & All & All & All & All & Small & Medium & Large \\
\hline $\begin{array}{l}\text { Log share of } \\
\text { immigrant children } \\
\text { aged 6-16 }\end{array}$ & $\begin{array}{c}-0.5735 \\
(0.0896) * \\
* *\end{array}$ & $\begin{array}{c}-0.5386 \\
(0.0871)^{*} \\
* *\end{array}$ & $\begin{array}{c}-0.5451 \\
(0.0894) * \\
* *\end{array}$ & $\begin{array}{c}-0.5296 \\
(0.0906) * \\
* *\end{array}$ & $\begin{array}{c}-0.4002 \\
(0.1123)^{*} \\
* *\end{array}$ & $\begin{array}{c}-0.4621 \\
(0.2549)^{*}\end{array}$ & $\begin{array}{c}-0.3428 \\
(0.4733)\end{array}$ \\
\hline $\begin{array}{l}\text { Log unemployment } \\
\text { rate }\end{array}$ & & $\begin{array}{c}0.2226 \\
(0.1824)\end{array}$ & $\begin{array}{c}0.2151 \\
(0.1817)\end{array}$ & $\begin{array}{c}0.1945 \\
(0.2173)\end{array}$ & $\begin{array}{c}0.6442 \\
(0.2748)^{*} \\
*\end{array}$ & $\begin{array}{c}0.0057 \\
(0.5464)\end{array}$ & $\begin{array}{c}0.5257 \\
(0.3993)\end{array}$ \\
\hline Log income & & $\begin{array}{l}-0.8841 \\
(1.3454) \\
\end{array}$ & $\begin{array}{l}-0.8833 \\
(1.3482) \\
\end{array}$ & $\begin{array}{l}-1.5892 \\
(1.4794)\end{array}$ & $\begin{array}{l}-2.6549 \\
(1.9885)\end{array}$ & $\begin{array}{l}-6.3001 \\
(3.8602)\end{array}$ & $\begin{array}{l}-2.6108 \\
(2.9448)\end{array}$ \\
\hline $\begin{array}{l}\text { Log local income } \\
\text { tax }\end{array}$ & & $\begin{array}{c}-3.1555 \\
(1.2961)^{*} \\
*\end{array}$ & $\begin{array}{c}-3.1456 \\
(1.2969)^{*} \\
*\end{array}$ & $\begin{array}{c}-4.4709 \\
(1.3589)^{*} \\
* *\end{array}$ & $\begin{array}{l}-3.0391 \\
(4.5348)\end{array}$ & $\begin{array}{l}-2.0544 \\
(2.2805)\end{array}$ & $\begin{array}{l}-3.6449 \\
(2.7840)\end{array}$ \\
\hline $\begin{array}{l}\text { Log public school } \\
\text { expenditure /pupil }\end{array}$ & & $\begin{array}{c}0.0241 \\
(0.2244)\end{array}$ & $\begin{array}{c}0.0123 \\
(0.2239)\end{array}$ & $\begin{array}{l}-0.0150 \\
(0.2337)\end{array}$ & $\begin{array}{c}0.1621 \\
(0.2800)\end{array}$ & $\begin{array}{c}0.5068 \\
(0.3143)\end{array}$ & $\begin{array}{l}-0.1311 \\
(0.4992)\end{array}$ \\
\hline Log adult population & & $\begin{array}{l}-2.9413 \\
(1.9422)\end{array}$ & $\begin{array}{l}-2.8949 \\
(1.9327)\end{array}$ & $\begin{array}{c}-6.6196 \\
(2.3142)^{*} \\
* *\end{array}$ & $\begin{array}{l}-0.5972 \\
(3.0645)\end{array}$ & $\begin{array}{l}-1.0282 \\
(6.2818)\end{array}$ & $\begin{array}{c}-13.6864 \\
(5.5923)^{*} \\
*\end{array}$ \\
\hline $\begin{array}{l}\text { Log share of higher } \\
\text { educated }\end{array}$ & & $\begin{array}{l}-0.8698 \\
(1.0394)\end{array}$ & $\begin{array}{l}-0.8639 \\
(1.0496)\end{array}$ & $\begin{array}{l}-1.0466 \\
(1.2375)\end{array}$ & $\begin{array}{c}0.6931 \\
(1.6918)\end{array}$ & $\begin{array}{l}-1.4702 \\
(1.7842)\end{array}$ & $\begin{array}{c}1.4481 \\
(1.9952)\end{array}$ \\
\hline Log housing prices & & & $\begin{array}{l}-0.0591 \\
(0.3489) \\
\end{array}$ & $\begin{array}{c}0.4310 \\
(0.4226) \\
\end{array}$ & $\begin{array}{c}0.0002 \\
(0.5712) \\
\end{array}$ & $\begin{array}{l}-0.1152 \\
(0.8467) \\
\end{array}$ & $\begin{array}{c}1.6731 \\
(0.8537)^{*}\end{array}$ \\
\hline $\begin{array}{l}\text { Regional trends } \\
\text { included }\end{array}$ & No & No & No & Yes & Yes & Yes & Yes \\
\hline Observations & 1227 & 1227 & 1225 & 1225 & 410 & 301 & 514 \\
\hline \# of municipalities & 208 & 208 & 207 & 207 & 117 & 46 & 44 \\
\hline R-squared & 0.141 & 0.167 & 0.169 & 0.322 & 0.742 & 0.615 & 0.444 \\
\hline
\end{tabular}

Note: Clustered standard errors in parentheses. * significant at 10\%; ** significant at 5\%; *** significant at $1 \%$. All estimations control for municipality fixed effects and include time dummies.

\subsection{Discussion and summary of results}

Before discussing the outcomes of regression estimations, a word of caution should be inserted. When reading the estimates I presuppose that the private schools that native Danes are choosing for their children have a lower share of pupils with immigrant background than the measured effects in the baseline estimations is a real effect rather than an artifact of unobserved trends or other factors. Results are available on request from the author. 
the public school they opt out from. From the data it is not possible to observe to what extent this holds true or not, but overall this is a reasonable supposition according to the figures on attendance rates presented in Table A1 and $\mathrm{A} 2 .^{26}$

The results presented in the previous section point to a positive association between increases in the share of pupils from countries outside Western Europe or OECD and enrolment rates into privately operated schools. To assess the magnitude of the estimates, back-of-theenvelope calculations indicate that a one standard deviation increase between 1992 and 2004 in the share of children with parents coming from countries outside the EU and OECD (i.e. a 64-percent change, corresponding to a change of about 2.1 percentage points, as calculated on the average share within the period 1992 to 2004) results in an increase in private school attendance rate of about 2.2 percent. $^{27}$ This corresponds to about 0.3 percentage points as calculated on the average share in the period 1992 to 2004 . Hence, on average an increase of 2.1 percentage points in the Share of children with parents coming from countries outside the $E U$ and OECD yields an increase in the private school attendance rate of 0.3 percentage points. ${ }^{28}$ Though this points to a rather moderate effect, it suggests that native flight has been present in Denmark.

\footnotetext{
${ }^{26}$ A similar argument is made in Betts and Fairlie (2003) and Fairlie and Resch (2002).

${ }^{27}$ As calculated by multiplying the ratio of a standard deviation and mean change in the share of immigrant children aged 6-16 with parents from countries outside the EU and OECD for all municipalities (see column (1) in Table A2) and the coefficient estimate from Table 2, column (4), i.e. [.021/.033]*0.0343.

${ }^{28}$ For their sample of 132 municipality areas, Betts and Fairlie (2003) estimate a 0.34 percentage point increase in private secondary schools attendance rate for natives following an increase of 1.06 percentage points in immigrant shares in the age group 7 to 16 for the period 1980 to 1990 . Notice that Betts and Fairlie look at private school attendance rates of native US-Americans, not attendance rates including immigrants. These are thus more comparable with the outcomes shown in Table 3.
} 
Some factors could have confounded determining the "true" elasticities. For example, this regards the fact that some parents could have succeeded in sending their children to another public school, in spite the directive rule of enrolment by place of residence. To the extent this has happened, it most likely would push the elasticity downwards. This follows from that opting for a free school in that case only will present one out of two options to select a preferred peer group, reducing free schools' marginal value for satisfying demands on sorting. Another aspect concerns that a number of once placed refugees moved away from their assigned municipality. The most common pattern was to move from smaller municipalities to places with a larger number of persons sharing the same ethnic background. What is the likely impact of such sorting for the found elasticities? As seen from Table 1, pupils from immigrant families more often attend public schools. Accordingly, a reduction in the number of children in the age group 6 to 16 belonging to families of once placed refugees will decrease the number of pupils enrolled in public schools in that municipality, causing the share of (remaining) pupils attending private schools to become larger simply as a mere compositional effect. Such mechanism suggests a negative relation between the share of pupils from countries outside Western Europe or OECD and enrolment rates into privately operated schools, and, again, will push the elasticity downwards. Taken together this implies that the presented elasticities most likely should be read as lower bounds.

As already pointed out, the outcomes vary noticeably across municipalities when splitting the sample by population size. In particular, the effect appears to be largest in medium sized communities. To some extent this might be the result of better access to private schools in 
such municipalities. ${ }^{29}$ However, this argument would lead us to expect to find even higher elasticities for larger municipalities. One explanation that this is not the case could be residence segregation, an argument also put forward by Betts and Fairlie (2003). By means of sorting into different neighborhoods (i.e., school districts) within the same municipality, parents will get a mix of peers they prefer for their children, i.e. they do not have to opt for private schools. ${ }^{30}$ Consistent with that hypotheses, for Denmark it has been found that immigrants from countries outside Western Europe or OECD countries are overrepresented in certain suburbs of the larger cities (see e.g. Schindler Rangvid, 2007).

\section{Conclusions}

From the present study it is not possible to determine what exactly lies behind parents' considerations when choosing schools, so the found correlations can as likely be attributed to rational aspects as outlined in the introduction, as well as (irrational) prejudices against immigrant groups. The latter aspect gains support by the result that pupils attending free schools in Denmark do not appear to perform very well as to their educational outcomes, as discussed previously. This suggests that parents partly are choosing schools for their children on other grounds than mere educational quality. Among others, such outcomes question those who advocate free school choice for the reason of achieving better educational standards. In case parents make their choices based on other grounds than school quality, one main requirement for achieving productivity gains will not be met.

\footnotetext{
${ }^{29}$ According to Andersen and Serritzlew (2007), in 2001 about one-third of the municipalities in Denmark did not have a private school within their boundaries, while about one-third had just one. The average numbers of public and free schools in each municipality were 6 and 2, respectively.

${ }^{30}$ This interpretation is in line with the main finding in Urquiola (2005), saying that an increase in school district availability reduces enrollment into private schools at the same time as it affects children's peer groups “with respect to both race and parental education,” p. 1310.
} 
Irrespective of causes, the findings in this paper point to stratification of school careers along ethnic and social lines. Ultimately, this questions the role of schools as a channel for integration and as a means for providing equal opportunities for subsequent academic careers as well as individual chances on the labor market. To certain extent the outcomes revealed in this study can be attributed to the very design of the voucher program that has been applied in Denmark, such as the tuition fees charged or the option for free schools to pick applicants. Irrespective such details, due to its intrinsic character as one of the few countries applying a large scale voucher program, the Danish educational system provide additional evidence to claims that school choice has a considerable impact in terms of sorting, while a positive impact on education standards seems rather questionable. 


\section{References}

Andersen, Simon Calmar and Søren Serritzlew. 2007. "The Unintended Effects of Private School Competition," Journal of Public Administration Research and Theory, Vol. 17: 335-356.

Andersen, Simon Calmar. 2008. "Private Schools and the Parents that Choose Them: Empirical Evidence from the Danish School Voucher System,” Scandinavian Political Studies, Vol. 31, pp. 44-68.

Angrist, J.D. and Lang, K. 2004. “Does school integration generate peer effects? Evidence from Boston's Metco Program," American Economic Review, Vol. 94, pp. 1613-1634.

Bayer, P., F. Ferreira and R. McMillan. 2007. “A Unified Framework for Measuring preferences for Schools and Neighborhoods," Journal of Political Economy, Vol. 115, pp. 588-638.

Betts, J. R. and R. W. Fairlie. 2003. "Does Immigration Induce 'Native Flight' from Public Schools into Private Schools?," Journal of Public Economics, Vol. 87 , pp. 987-1012.

Betts, J. R. and R. W. Fairlie. 2001. "Explaining Ethnic, Racial, and Immigrant Differences in Private School Attendance," Journal of Urban Economics, Vol. 50, pp. 26-51.

Bifulco, Robert, Ladd Helen F., and Ross, Stephen L. 2009. "Public school choice and integration evidence from Durham, North Carolina," Social Science Research, pp. 71-85.

Brunner, Eric J. and Jennifer Imazeki. 2008. “Tiebout choice and universal school vouchers,” Journal of Urban Economics, Vol. 63, pp. 253-279

Böhlmark, Anders and Mikael Lindahl. 2007. “The Impact of School Choice on Educational Performance, Segregation and Cost: Swedish Evidence,” IZA Discussion Paper No. 2786.

Card, David. 2007. “How Immigration Affects U.S. Cities,” CReAM Discussion Paper N. 11/07, London UK.

Cellini, Stephanie Riegg, Ferreira, Fernando V. and Rothstein, Jesse, 2008. "The Value of School Facilities: Evidence from a Dynamic Regression Discontinuity Design,” NBER Working Paper No. w14516.

Clark, Ken and Joanne Lindley. 2009. Immigrant assimilation pre and post labour market entry: evidence from the UK Labour Force Survey,” Journal of Population Economics, Vol. 22, pp. 175-198.

Cohen-Zada, Danny. 2006. "Preserving religious identity through education: Economic analysis and evidence from the US," Journal of Urban Economics Vol. 60, pp. 372-398.

Cullen, J., B. Jacob and S. Levitt. 2005. "The Impact of School Choice on Student Outcomes: An Analysis of the Chicago Public Schools,” Journal of Public Economics, Vol. 89, 729-760.

Danish Ministry of Education. 2008. "Private Schools in Denmark," http://www.eng.uvm.dk/ /media/Files/English/Fact\%20sheets/080101_fact_sheet_private_schools.ashx

Danish Ministry of Foreign Affairs. 2008. "The Danish educational system and society," http://www.studyindenmark.dk/student-life/about-denmark-1/danish-educational-system-and-society

Damm, A. P. (2009), “Ethnic Enclaves and Immigrant Labour Market Outcomes: Quasi Experimental Evidence," Journal of Labor Economics 27, 281-314.

Dottori, Davide and Shen, I-Ling. 2009. "Low-Skilled Immigration and the Expansion of Private Schools," IZA Discussion Paper No. 3946.

Fairlie, Robert W. and Alexandra M. Resch. 2002. "Is there "White Flight" into private schools? Evidence from the National Educational Longitudinal Survey," Review of Economics and Statistics, Vol. 84, pp. 21-33. 
Gerdes, Christer. 2009. "The Impact of Immigration on the Size of Government: Empirical Evidence from Danish Municipalities," APSA 2009 Toronto Meeting Paper. Available at SSRN: http://ssrn.com/abstract=1450327

Gibbons, Stephen, Stephen Machin and Olmo Silva. 2008. "Choice, Competition and Pupil Achievement," Journal of the European Economic Association, Vol. 6, pp. 912-947.

Gould, Eric D. Victor Lavy, M. Daniele Paserman. 2009. "Does Immigration Affect the Long-Term Educational Outcomes of Natives? Quasi-Experimental Evidence," Vol. 119, pp.1243-1269.

Guryan, J. 2004. "Desegregation and black dropout rates," American Economic Review, Vol. 94, pp. 919-943.

Hanushek, Eric A., John F. Kain, Steven G. Rivkin and Gregory F. Branch. 2007. "Charter school quality and parental decision making with school choice," Journal of Public Economics Vol. 91, pp. 823-848.

Hsieh, Chang-Tai, and Miguel Urquiola. 2006. "The Effects of Generalized School Choice on Achievement and Stratification: Evidence from Chile's Voucher Program,” Journal of Public Economics Vol. 90, pp. $1477-$ 1503.

Johnson, Joyce Dinwiddie. 1997. “What Is an Efterskole?” Annual AEE International Conference Proceedings. http://www.eric.ed.gov/ERICDocs/data/ericdocs2sq1/content_storage_01/0000019b/80/15/12/ca.pdf

Ladd, Helen F. 2002. "School Vouchers: A Critical View," Journal of Economic Perspectives, Vol. 16, pp. 3-24. Nannestad, Peter. 2004. "Do private schools improve the quality of municipal schooling? The case of Denmark," Paper for presentation at the EPCS Annual Meeting, Berlin, April 15-18, 2004.

Rothstein, Jesse M. 2006. "Good Principals or Good Peers? Parental Valuation of School Characteristics, Tiebout Equilibrium, and the Incentive Effects of Competition among Jurisdictions," American Economic Review, Vol. 96, pp. 1333-1350.

Schindler Rangvid, Beatrice. 2007. "Living and Learning Separately? Ethnic Segregation of School Children in Copenhagen," Urban Studies, Vol. 44, pp. 1329-1354.

Schindler Rangvid, Beatrice. 2008. "Private School Diversity in Denmark's National Voucher System," Scandinavian Journal of Educational Research, Vol. 52, pp. 331-354

Schindler Rangvid, Beatrice. 2009. "School Choice, Universal Vouchers and Native Flight from Local Schools," European Sociological Review, doi:10.1093/esr/jcp024.

Tedin, K.L., and Weiher, G.R. 2004. "Racial/ethnic diversity and academic quality as components of school choice," Journal of Politics, Vol. 66, pp. 1109-1133.

Urquiola, Miguel. 2005. "Does School Choice Lead to Sorting? Evidence from Tiebout Variation," American Economic Review, Vol. 95, pp. 1310-1326.

Wooldridge, Jeffrey M. 2002. "Econometric Analysis of Cross Section and Panel Data," Cambridge, MA: MIT Press 


\section{Appendix}

Table A1. Summary Statistics: Means in variables in 1992 (Standard deviations in parentheses). Municipality level.

\begin{tabular}{|c|c|c|c|c|}
\hline private school attendance rate & $\begin{array}{r}\text { Municipalities in } \\
\text { Sample } \\
.113 \\
(.099)\end{array}$ & $\begin{array}{r}\text { Population }< \\
10,000 \\
.109 \\
(.112)\end{array}$ & $\begin{array}{r}\text { Population } \\
10,000-20,000 \\
.110 \\
(.073)\end{array}$ & $\begin{array}{r}\text { Population }> \\
20,000 \\
.133 \\
(.062)\end{array}$ \\
\hline $\begin{array}{l}\text { private school attendance rate, } \\
\text { pupils with Danish born parents }\end{array}$ & $\begin{array}{r}.114 \\
(.099)\end{array}$ & $\begin{array}{r}.109 \\
(.112)\end{array}$ & $\begin{array}{r}.112 \\
(.075)\end{array}$ & $\begin{array}{r}138 \\
(.065)\end{array}$ \\
\hline $\begin{array}{l}\text { private school attendance rate, }{ }^{1} \\
\text { pupils with parents from }\end{array}$ & $\begin{array}{r}.077 \\
(.203)\end{array}$ & $\begin{array}{r}.103 \\
(.265)\end{array}$ & $\begin{array}{r}.046 \\
(.151)\end{array}$ & $\begin{array}{r}.061 \\
(.060)\end{array}$ \\
\hline $\begin{array}{l}\text { countries outside the EU and } \\
\text { OECD }\end{array}$ & & & & \\
\hline $\begin{array}{c}\text { share of children aged 6-16 with } \\
\text { parents from countries outside }\end{array}$ & $\begin{array}{l}0.018 \\
(.030)\end{array}$ & $\begin{array}{l}0.007 \\
(.010)\end{array}$ & $\begin{array}{l}0.025 \\
(.037)\end{array}$ & $\begin{array}{l}0.055 \\
(.041)\end{array}$ \\
\hline the EU and OECD & & & & \\
\hline unemployment rate & $\begin{array}{r}.065 \\
(.016)\end{array}$ & $\begin{array}{r}.067 \\
(.016)\end{array}$ & $\begin{array}{r}.061 \\
(.017)\end{array}$ & $\begin{array}{r}.061 \\
(.014)\end{array}$ \\
\hline average household income & $\begin{array}{r}104587.90 \\
(21121.040)\end{array}$ & $\begin{array}{r}99695.52 \\
(19785.730)\end{array}$ & $\begin{array}{r}113779.10 \\
(23802.090)\end{array}$ & $\begin{array}{r}113419.70 \\
(16239.840)\end{array}$ \\
\hline local income tax rates & $\begin{array}{l}28.800 \\
(2.783)\end{array}$ & $\begin{array}{r}28.683 \\
(3.292)\end{array}$ & $\begin{array}{r}28.585 \\
(1.511)\end{array}$ & $\begin{array}{l}29.536 \\
(1.080)\end{array}$ \\
\hline $\begin{array}{l}\text { public school expenditure per } \\
\text { pupil (in thousand } \mathrm{dkr})^{2}\end{array}$ & $\begin{array}{r}39.650 \\
(75.568)\end{array}$ & $\begin{array}{r}40.402 \\
(93.243)\end{array}$ & $\begin{array}{r}35.679 \\
(9.714)\end{array}$ & $\begin{array}{r}41.394 \\
(21.461)\end{array}$ \\
\hline adult population & $\begin{array}{r}14717.180 \\
(30401.910)\end{array}$ & $\begin{array}{r}5975.233 \\
(1919.659)\end{array}$ & $\begin{array}{r}13565.600 \\
(2192.104)\end{array}$ & $\begin{array}{r}51866.820 \\
(64634.970)\end{array}$ \\
\hline share of higher educated & $\begin{array}{r}.092 \\
(.036)\end{array}$ & $\begin{array}{r}.082 \\
(.023)\end{array}$ & $\begin{array}{r}.105 \\
(.050)\end{array}$ & $\begin{array}{r}.115 \\
(.041)\end{array}$ \\
\hline housing prices (in thousand $\mathrm{dkr}$ ) & $\begin{array}{r}480.376 \\
(174.379)\end{array}$ & $\begin{array}{r}411.322 \\
(114.496)\end{array}$ & $\begin{array}{r}558.359 \\
(175.151)\end{array}$ & $\begin{array}{r}668.932 \\
(199.178)\end{array}$ \\
\hline
\end{tabular}

Note: ${ }^{1}$ Relevant observations for 183 (88) out of $275 \overline{(178) \text { in all (in small) municipalities; }{ }^{2} \text { public school }}$ expenditures per pupil have been calculated by approximating the total number of pupils according to the number of pupils attending grade 8 and 9, assuming that the numbers attending grade 1 to 7 have been of similar size. On average this should be seen as a reasonable approximation, as seen by the figures on number of pupils attending folkeskole for the year 2007.

\begin{tabular}{lrrrrrrrr}
\hline 1. class & 2. class & \multicolumn{1}{l}{ 3. class } & 4. class & 5. class & 6. class & 7. class & 8. class & 9. class \\
\hline 55798 & 54847 & 54215 & 55402 & 54733 & 56849 & 55679 & 53295 \\
\hline
\end{tabular}


Table A2. Summary Statistics: Means of differences in variables between 1992 and 2004 (Standard deviations in parentheses). Municipality level.

\begin{tabular}{|c|c|c|c|c|}
\hline \multirow[b]{2}{*}{$\Delta$ private school attendance rate } & $\begin{array}{r}\text { All } \\
\text { Municipalities }\end{array}$ & Population $<10,000$ & $\begin{array}{r}\text { Population } \\
10,000-20,000\end{array}$ & $\begin{array}{r}\text { Population }> \\
20,000\end{array}$ \\
\hline & $\begin{array}{r}.024 \\
(.055)\end{array}$ & $\begin{array}{r}.026 \\
(.064)\end{array}$ & $\begin{array}{r}.017 \\
(.036)\end{array}$ & $\begin{array}{r}.024 \\
(.036)\end{array}$ \\
\hline $\begin{array}{l}\Delta \text { private school attendance rate, } \\
\text { pupils with Danish born parents }\end{array}$ & $\begin{array}{r}.028 \\
(.057)\end{array}$ & $\begin{array}{r}.029 \\
(.065)\end{array}$ & $\begin{array}{r}.022 \\
(.038)\end{array}$ & $\begin{array}{r}.030 \\
(.037)\end{array}$ \\
\hline $\begin{array}{l}\Delta \text { private school attendance rate, } \\
\text { pupils with parents from }\end{array}$ & $\begin{array}{r}-.017 \\
(.203)\end{array}$ & $\begin{array}{r}-.046 \\
(.264)\end{array}$ & $\begin{array}{r}-.005 \\
(.151)\end{array}$ & $\begin{array}{r}.025 \\
(.054)\end{array}$ \\
\hline countries outside the EU and & & & & \\
\hline OECD & & & & \\
\hline $\begin{array}{l}\Delta \text { share of children aged 6-16 } \\
\text { with parents from countries }\end{array}$ & $\begin{array}{r}.033 \\
(.021)\end{array}$ & $\begin{array}{r}.026 \\
(.012)\end{array}$ & $\begin{array}{r}.036 \\
(.024)\end{array}$ & $\begin{array}{r}.054 \\
(.029)\end{array}$ \\
\hline outside the EU and OECD & & & & \\
\hline$\Delta$ unemployment rate & $\begin{array}{r}-.034 \\
(.012)\end{array}$ & $\begin{array}{r}-.035 \\
(.012)\end{array}$ & $\begin{array}{r}-.031 \\
(.012)\end{array}$ & $\begin{array}{r}-.032 \\
(.010)\end{array}$ \\
\hline$\Delta$ average household income & $\begin{array}{r}51834.62 \\
(13400.3)\end{array}$ & $\begin{array}{r}51309.51 \\
(14468.79)\end{array}$ & $\begin{array}{r}52772.74 \\
(11673.97)\end{array}$ & $\begin{array}{r}52814.4 \\
(10751.52)\end{array}$ \\
\hline$\Delta$ local income tax rates & $\begin{array}{r}3.378 \\
(4.727)\end{array}$ & $\begin{array}{r}3.457 \\
(5.229)\end{array}$ & $\begin{array}{r}3.428 \\
(4.831)\end{array}$ & $\begin{array}{r}2.995 \\
(1.102)\end{array}$ \\
\hline $\begin{array}{l}\Delta \text { public school expenditure per } \\
\text { pupil (in thousand } \mathrm{dkr} \text { ) }\end{array}$ & $\begin{array}{r}29.364 \\
(35.874)\end{array}$ & $\begin{array}{r}31.236 \\
(42.934)\end{array}$ & $\begin{array}{r}27.931 \\
(10.804)\end{array}$ & $\begin{array}{r}23.656 \\
(21.129)\end{array}$ \\
\hline$\Delta$ adult population & $\begin{array}{r}317.993 \\
(1873.139)\end{array}$ & $\begin{array}{r}42.911 \\
(941.945)\end{array}$ & $\begin{array}{r}159.717 \\
(1801.825)\end{array}$ & $\begin{array}{r}1633.977 \\
(3575.101)\end{array}$ \\
\hline$\Delta$ share of higher educated & $\begin{array}{r}.0317198 \\
(.014)\end{array}$ & $\begin{array}{r}.029494 \\
(.012)\end{array}$ & $\begin{array}{r}.0321431 \\
(.013)\end{array}$ & $\begin{array}{l}.040 \\
(.020)\end{array}$ \\
\hline $\begin{array}{l}\Delta \text { housing prices (in thousand } \\
\mathrm{dkr} \text { ) }\end{array}$ & $\begin{array}{r}624.359 \\
(425.792)\end{array}$ & $\begin{array}{r}482.914 \\
(242.940)\end{array}$ & $\begin{array}{r}744.192 \\
(460.532)\end{array}$ & $\begin{array}{r}1042.091 \\
(606.868)\end{array}$ \\
\hline
\end{tabular}


Table A3. Dependent variable: Log of private school attendance rate. Estimations as in Table 2, but weighted by adult population size.

\begin{tabular}{|c|c|c|c|c|c|c|c|}
\hline & (1) & (2) & (3) & (4) & (5) & (6) & (7) \\
\hline & All & All & All & All & Small & Medium & Large \\
\hline $\begin{array}{l}\text { Log share of } \\
\text { immigrant children } \\
\text { aged 6-16 }\end{array}$ & $\begin{array}{l}0.0616 \\
(0.0187) * \\
* *\end{array}$ & $\begin{array}{c}0.0408 \\
(0.0181)^{*} \\
*\end{array}$ & $\begin{array}{l}0.0326 \\
(0.0181)^{*}\end{array}$ & $\begin{array}{c}0.0445 \\
(0.0187) * \\
*\end{array}$ & $\begin{array}{l}0.0375 \\
(0.0231)\end{array}$ & $\begin{array}{l}0.0443 \\
(0.0519)\end{array}$ & $\begin{array}{l}-0.0129 \\
(0.0941)\end{array}$ \\
\hline $\begin{array}{l}\text { Log unemployment } \\
\text { rate }\end{array}$ & & $\begin{array}{l}-0.0528 \\
(0.0524)\end{array}$ & $\begin{array}{l}-0.0694 \\
(0.0549)\end{array}$ & $\begin{array}{l}-0.0050 \\
(0.0634)\end{array}$ & $\begin{array}{l}-0.0680 \\
(0.0978)\end{array}$ & $\begin{array}{l}-0.0207 \\
(0.1481)\end{array}$ & $\begin{array}{l}0.0381 \\
(0.0948)\end{array}$ \\
\hline Log income & & $\begin{array}{l}1.6005 \\
(0.4668)^{*} \\
* *\end{array}$ & $\begin{array}{l}1.6365 \\
(0.4763)^{*} \\
* *\end{array}$ & $\begin{array}{l}1.3237 \\
(0.4403)^{*} \\
* *\end{array}$ & $\begin{array}{l}0.1219 \\
(0.7509)\end{array}$ & $\begin{array}{l}0.4378 \\
(1.0615)\end{array}$ & $\begin{array}{l}0.7947 \\
(0.7732)\end{array}$ \\
\hline $\begin{array}{l}\text { Log local income } \\
\operatorname{tax}\end{array}$ & & $\begin{array}{l}-0.0994 \\
(0.4040)\end{array}$ & $\begin{array}{l}-0.1920 \\
(0.3838)\end{array}$ & $\begin{array}{l}-0.6798 \\
(0.4325)\end{array}$ & $\begin{array}{l}0.2330 \\
(1.0233)\end{array}$ & $\begin{array}{l}-1.7182 \\
(0.9039)^{*}\end{array}$ & $\begin{array}{c}-1.5774 \\
(0.7064)^{*} \\
*\end{array}$ \\
\hline $\begin{array}{l}\text { Log public school } \\
\text { expenditure /pupil }\end{array}$ & & $\begin{array}{l}0.1938 \\
(0.1609)\end{array}$ & $\begin{array}{l}0.1869 \\
(0.1612)\end{array}$ & $\begin{array}{l}0.1590 \\
(0.1640)\end{array}$ & $\begin{array}{l}0.6742 \\
(0.2042)^{*} \\
* *\end{array}$ & $\begin{array}{l}0.4340 \\
(0.1329)^{*} \\
* *\end{array}$ & $\begin{array}{l}0.0919 \\
(0.2124)\end{array}$ \\
\hline Log adult population & & $\begin{array}{l}-1.2218 \\
(0.6657)^{*}\end{array}$ & $\begin{array}{l}-1.0865 \\
(0.6479)^{*}\end{array}$ & $\begin{array}{c}-0.8627 \\
(0.8066)\end{array}$ & $\begin{array}{l}0.3824 \\
(0.9193)\end{array}$ & $\begin{array}{l}-4.4375 \\
(2.2765)^{*}\end{array}$ & $\begin{array}{c}-1.4009 \\
(1.7252)\end{array}$ \\
\hline $\begin{array}{l}\text { Log share of higher } \\
\text { educated }\end{array}$ & & $\begin{array}{c}-0.7291 \\
(0.2206)^{*} \\
* *\end{array}$ & $\begin{array}{l}-0.6615 \\
(0.2347)^{*} \\
* *\end{array}$ & $\begin{array}{l}-0.4286 \\
(0.3511)\end{array}$ & $\begin{array}{c}0.2727 \\
(0.5436)\end{array}$ & $\begin{array}{c}0.2829 \\
(0.7184)\end{array}$ & $\begin{array}{l}-0.2724 \\
(0.7265)\end{array}$ \\
\hline Log housing prices & & & $\begin{array}{c}-0.1398 \\
(0.1184)\end{array}$ & $\begin{array}{l}-0.0345 \\
(0.1525)\end{array}$ & $\begin{array}{c}-0.1539 \\
(0.1721)\end{array}$ & $\begin{array}{c}-0.4023 \\
(0.4500)\end{array}$ & $\begin{array}{c}0.3964 \\
(0.3315)\end{array}$ \\
\hline $\begin{array}{l}\text { Regional trends } \\
\text { included }\end{array}$ & No & No & No & Yes & Yes & Yes & Yes \\
\hline Observations & 3378 & 3378 & 3373 & 3373 & 2116 & 685 & 572 \\
\hline \# of municipalities & 275 & 275 & 275 & 275 & 178 & 53 & 44 \\
\hline R-squared & 0.070 & 0.090 & 0.093 & 0.241 & 0.255 & 0.486 & 0.481 \\
\hline
\end{tabular}

Note: Clustered standard errors in parentheses. ${ }^{*}$ significant at $10 \% ; * *$ significant at $5 \% ; * * *$ significant at $1 \%$. All estimations control for municipality fixed effects and include time dummies. 